only twenty-three years old. He identified, and named, "the isotope" (p. 46); "In America, the University of California built a small machine, called the 'cyclotron', for the head of its radiation laboratory, Professor E. O. Lawrence" (p. 68); "Swanage, Hampshire" (p. 76).

Here is merely a selection from a multitude of statements starkly erroneous, grossly misleading or merely inept. In total they render the book worthless for readers of any class.

Perhaps the most surprising feature of all is that there should be a foreword by Sir John Cockeroft: "I hope that this book will inspire young people to take up the study of science seriously". I cannot see how Sir John can fail to be disappointed in the upshot: indeed the publishers would be well advised to eut their losses and withdraw the book. It can do them no good-nor its young readers, either.

N. Feather

\section{BLACK, WATT, PRIESTLEY, CAVENDISH AND THEIR CONTEMPORARIES}

Scientists of the Industrial Revolution

Joseph Black-James Watt-Joseph Priestley-Henry Cavendish. By J. G. Crowther. Pp. xii $+365+7$ plates. (London: The Cresset Press, Ltd., 1962.) 35s. net.

\section{T}

HIS is the last of five books "in which British science

has been viewed through biographies of a succession of leading figures in its creation". It deals with the period when the "British Empire and modern industrialism were born at the same time, of the same forces". The book presents a wide vista. Under "Black" there is much about Cullen, Adam Smith and Hutton; the section headed Watt has chapters on Roebuck and Boulton; "Priestley" brings in many others-chiefly Wedgwood and E. Darwin; and "Cavendish" introduces further personalities, including Captain James Cook and Joseph Banks. These are excellent studies, though occasionally the author appears to have jumped to conclusions from incomplete evidence.

The tendency to impose a particular point of view will not please all readers. One of the author's interesting simplifications is that science before about 1754 was subservient to a mercantile nation, and that after this time (which, incidentally, coincided with the foundation of the Society of Arts) it was largely re-orientated to serve the needs of an industrial country. Mathematies, astronomy and navigation are identified with the former, physics and chemistry with the latter. By 'physics' the author means the newer subjects of electricity and heat rather than established branches of science like mechanics and optics, these being of obvious importance in astronomy, navigation and engineering. Thus this view does not quite fit the facts. Economic and social factors alone do not $\theta x$ plain why the sciences developed at different rates.

Crowther's "Conclusion" does not emerge naturally. It ends with the contention that British science has declined and will continue to do so until "there is a publicly owned and controlled productive system"-an idea that would have sounded strange to several of the rugged individualists portrayed here.

That Gowland Hopkins first referred to "vitamins" (actually "minimal qualitative factors") in an address to the Society of Public Analysts rather than to a medical society had nothing to do with resistance to social exploitation by industry. Hopkins, in 1906, was diseussing professional difficulties between public analysts and medical officers of health. $\mathrm{He}$ was speaking of the kind of work that awaited analysts in the field of physiological chemistry, for which analytical training was at that time inadequate. The chemists at first had difficulty in understanding Hopkins's evidence, and the medical profession did not become convinced by it for several years.
By all means let us have, and be grateful for, stimulating and provocative writing, but let us also try not to misread the facts. F. W. GIBBs

\section{PHOTOGRAPHIC SCIENCE}

\section{Scientific Photography}

Proceedings of the International Colloquium held at Liege 1959; Sponsored by the Patrimoine de l'Universite de Liège. Edited by Dr. H. Sauvenier. Pp. $x x+617$. (Oxford, London, New York and Paris : Symposium Publications Division, Pergamon Press, 1962.) £10.

THIS book contains the papers presented at an international colloquium at Liège in 1959 and also a record of the discussions. The papers are arranged in sections on-crystals, fundamental processes, role of gelatine, chemical sensitization, errors of reciprocity (reciprocity failure) and optical sensitization. The contributions include invited papers of a review nature and reports on new work. A novel feature of the colloquium was an invitation to the participants to submit questions dealing with problems of general interest in the field of photographic science. These questions and the ensuing discussions are recorded in the appropriate sections of the colloquium proceedings.

More than half the contributions in the section on crystals are review papers, including a comprehensive one by F. C. Brown and F. C. Seitz on electronic processes in silver halides. Several papers on latent image theory appear in the section on fundamental processes. The contribution by W. West and V. I. Saunders describes elegant experiments with single silver bromide crystals which provide evidence for the dual role of silver sulphide as traps for both electrons and positive holes. The full discussion on the theory of photographic sensitivity indicates the interest that this topic aroused at the colloquium. J. W. Mitchell, in a contribution submitted after the colloquium, presents his views on photographic sensitivity and deals with many of the points raised in general discussion.

The section on the role of gelatine is introduced by a review from $J$. Pouradier on the photographic function of gelatine. Other papers deal with the mechanism of gelation and the part played by gelatine in the process of chemical sensitization. The section on the latter process includes a discussion of several questions on the nature of sensitivity centres and fog specks.

B. H. Carroll's excellent review of the process of optical sensitization is followed by several papers on the structure of sensitizing dyes and the mechanism of adsorption to silver halide crystals. Other papers discuss the alternative possibilities of energy or electron transfer in the sensitization process.

The value of publishing conference proceedings in a volume of the type under review is, however, questionable. The price is prohibitive, and many of the papers appeared in print elsewhere a year or two before this volume was published. Quicker and cheaper publication in a lesselaborate form would be of greater value to the conference participants.

H. O. DiCKINSON

\section{MAYA DECADENCE}

\section{Mayapán, Yucatan, Mexico}

By H. E. D. Pollock, Ralph L. Roys, T. Proskouriakoff and A. Ledyard Smith. (Publication No. 619.) Pp. v+ $442+89$ figures. (Washington: Carnegie Institution of Washington, 1962.) 9.00 dollars paper bound; 9.50 dollars cloth bound.

THE last great work of the Department of Archæology (which is now virtually defunct) of the Carnegie Institution of Washington was the excavation of the last 